\title{
ASSESSING THE INDONESIAN CONSTITUTIONAL COURT CONSISTENCY IN DETERMINING ITS AUTHORITY TO SETTLE DISPUTE ON REGIONAL HEAD ELECTION
}

\author{
Andy Omara ${ }^{1}$ \\ ${ }^{1}$ Faculty of Law, Universitas Gadjah Mada \\ E-mail: andy.omara@mail.ugm.ac.id
}

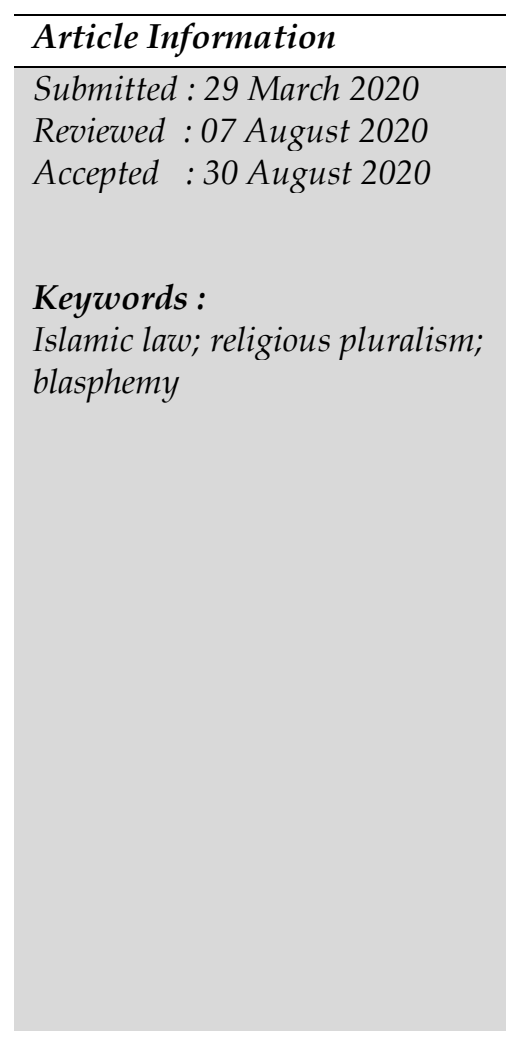

\begin{tabular}{l} 
Abstract \\
\hline This study aims to answer three important questions: first, how the \\
1945 Constitution regulate the authority of the Constitutional \\
Court in resolving dispute on general election as stated in Article \\
22 E and the regional head election as stipulated in Article 18. \\
Second, how the Constitutional Court, through its rulings, \\
interpret its authority to settle dispute on general election and \\
regional head election. Third, why, in different period, there is a \\
tendency that the Court provide different interpretation regarding \\
its authority to resolve dispute on general election and regional \\
head election. To answer these three questions, this study utilizes \\
doctrinal approach. It analyses the relevant laws and regulation and \\
also the relevant Court rulings. This study concludes that (1) the \\
1945 Constitution expressly differentiate between regional head \\
election and general election. However, (2) the Court provide \\
different interpretation on determining the nature of regional head \\
election specifically on whether such an election include in the \\
category of general election or it is a distinct election. (3) There are \\
two main factors that may explain why the Court provide different \\
explanation regarding its power to settle dispute on the regional \\
head election and general election (1) the provision of the \\
constitution and the relevant law (election law and local \\
governance law) and (2) corruption cases which involved the chief \\
justice of constitutional court.
\end{tabular}

\section{Introduction.}

The most recent constitutional amendments in 1999-2002 have substantially changed the characteristics of the 1945 Constitution (Valina Singka Subekti, 2008: 69). These amendments established three new state institutions: two judicial institutions and one chamber of the legislature. The Introduction of two judicial institutions namely the Judicial Commission (the KY-Komisi Yudisial) and the Constitutional Court (the MKMahkamah Konstitusi) besides the Supreme Court (the MA-Mahkamah Agung) changed the structure of the judiciary (Tim Lindsey, 2008: 34). In the past, judicial power was concentrated in the MA. After the amendments, judicial powers are distributed into three 
different institutions the MA, the MK and the KY. With regards to the KY, some scholars believe that the KY is not part of judicial institution. This is because the KY does not adjudicate cases. It does not settle disputes. It is instead supervising the MA justice's behavior and is involved in the MA justices' recruitment. However, the updated Constitution include the KY in the Chapter on Judiciary besides the MK and the MA. The MA and the MK settle disputes while the KY deals with the nomination of the MA Justices and maintain the dignity and attitudes of Justices (Art 24A, 24B, 24C of the 1945 Constitution).

The updated Constitution also inserted Regional Representative Council (the DPD-Dewan Perwakilan Daerah). The DPD aims to represent the voice of the regions (Simon Butt and Tim Lindsey, 2012: 5). The roles of the DPD is somewhat similar to the roles of Senate in federal countries. The introduction of the DPD in the updated Constitution change the Indonesian parliament from unicameral to two-chamber parliament system or commonly called bicameral system. Bicameral system implemented in Indonesia is somewhat unique. Some scholars believe that Indonesia adopts soft bicameral system (weak bicameral system) because there is a huge difference between the authority and the number of the members of the first chamber and the second chamber. But there is an opinion which states that Indonesia adopts three chamber system because there are three different chambers: the DPR the DPD and the MPR. This view however is not that popular because the MPR often viewed as joint session between member of the DPR and member of the DPD rather than a separate body.

The introduction of these three new institutions raise several important questions, such as what explains the establishment of these three state institutions? and how these state bodies understand and interpret their constitutional authorities when they exercise their powers? This study does not intent to discuss all the three new institutions, rather it focuses on one branch of government namely the judiciary. It puts special attention on the formulation of the new, separate Court -the Constitutional Court -the MK (Hikmahanto Juwana, 2014: 311). The MK is chosen for two reasons: first, the MK is a new state institution which considerably change the structure of judicial powers. Second, The MK possess four important constitutional powers i.e. judicial review, settling disputes among state institutions, dismissing political parties, providing legal consideration on impeachment motion, and settling dispute on general elections. This study will particularly examine the MK power to settle dispute on general elections specifically dispute on regional head election.

The Updated Constitution clearly stipulates the powers of the MK. Article 24 of the 1945 Constitution says: (1) The Constitutional Court shall possess the authority to try a case at the first and final level and shall have the final power of decision in reviewing laws against the Constitution, determining disputes over the authorities of state institutions whose powers are given by this Constitution, deciding over the dissolution of a political party, and deciding disputes over the results of general elections. The Constitutional Court, based on the above article, has the power to resolve dispute on general elections. It further differentiates elections into two: general election (Art. 22E) and regional head election (Art. 18 (4)). Based on Article 22 E, general elections consist of 
four different elections: Presidential and Vice-Presidential Election (the Pilpres), election of members of Regional Representative Council (pemilu anggota DPD), election of members of People Representative Council (pemilu anggota DPR) and election of member of local parliament (pemilu anggota DPRD). These elections are different from regional head elections as mentioned in Article 18. These two constitutional provisions become the constitutional bases of the MK to limit its powers only to settle dispute on general elections -not regional head elections.

The first generation of the MK (2003-2008) consistently used this approach excluding settling dispute on regional head elections as its authority. This approach changes significantly after the enactment of the new Act on Regional Governance in 2007 which broaden the meaning of general elections not only the general elections as mentioned in Article $22 \mathrm{E}$ but also regional head elections as stipulated Article 18 (4). This 2007 Law expands the power of the MK to settle dispute on regional head elections (Art. 18(4)) besides other types of general elections (as mentioned in Art 22E). The extensive power of the MK is not because of the provision of the Constitution or the court decision but it is because of the Act on General Election which include regional head election as part of general elections regime. The extensive powers of the MK to settle dispute on elections changed again when Justice Hamdan Zoelva was the Chief Justice of Constitutional Court. Instead of maintaining its extensive power, the Court returned to its limited original powers as mentioned in article 22E. The main topics that will be addressed in this study are: what explains the dynamic changes regarding the authority of the Court to settle dispute on elections and why the Court return to its original power in settling dispute on general elections. Based on the above mentioned, this study aims to answer three important research questions, as follow:

1. How the updated 1945 Constitution stipulate the MK authorities in settling dispute in general elections if it is connected with Article $22 \mathrm{E}$ and Article 18 (4) of the Constitution?

2. Why does the Court authority to resolve dispute on general elections and regional head elections dynamically change considering the provision of the Constitution remain the same?

\section{Research Methods}

This is a normative legal research. It aims to answer three questions. In responding these three questions this study uses doctrinal approaches and content analysis. To answer question one, the author studies the text of the Constitution, the minutes of the constitutional amendments, and some scholar's opinions as reflected in some law journals. To respond research question two, the author analyses some relevant laws such law Laws 22/2007, Law 12/2008 and Law 7/ 2017 and some relevant Constitutional Court rulings. In answering question three, the author interprets the Court attitude against its power to settle dispute on regional head election by understanding the legal and extralegal factors which may involve in determining the court competence in settling dispute on regional head election. 


\section{Research result and Discussion}

\section{A. Background on the establishment of the MK}

The existing literatures provide different explanation regarding the establishment of a constitutional court. Tom Ginsburg states that the birth of constitutional court in some Asian countries is dominated by political insurance (Tom Ginsburg, 2003: 33). For him the existence of a constitutional court heavily influenced by a situation where ruling political party believe that it cannot dominate the parliament anymore in the next election. in such situation, this political party will endorse the establishment of a constitutional court. This is because the Court will be a channel for this political party to challenges the policy of the next government. In the contexts of Egypt, Tamir Moustafa asserts that the birth of supreme constitutional court motivated by economic interest i.e. to attract foreign investor to invest their fund in Egypt (Tamir Mustafa and Tom Ginsburg 2008: 4). The Supreme Constitutional Court improve the confidence of investors because there is an avenue their can use in case the government issue policies that is inconsistent with the Constitution.

In Indonesia, the establishment of the MK can be explained into four possible related explanations. Some of these four reasons are similar to other countries experience when they establish similar institution. the Korean Constitutional Court for example was established to uphold the constitutional rights of the citizens and also transition from authoritarian to emerging democracy.

First, the impeachment of President Abdurrahman Wahid (Gus Dur) during his term of office often become the reason to establish the MK (Jimly Asshidiqie 2009: 2). Some countries including the USA does not have a Constitutional Court, however, the US Supreme Court play important roles in the impeachment process. The pure political motives in impeaching Gus Dur become a trigger how important the existence of a legal institution which can intervene the pure political motive in the impeachment of president (Petra Stockmann, 2007: 14). This argument can explain why the Court has power to provide legal advice in impeachment motion.

Second, the history of judicial review in Indonesia. While the constitution of Indonesia recognizes judicial review in the most recent constitutional amendments (19992002), the idea of having an institution that have an authority to conduct judicial review were not new (Tim Penyusun, 2008: 5). In 1945 when the founding fathers drafted the first Constitution, this idea has been debated. One view believe that it is not necessary to include judicial review in the Constitution. Four possible arguments explain this position: first, it is not clear whether the question put into judicial review is legal or political question. Second, Indonesia does not adopt strict separation of powers therefore judicial review does not apply to Indonesia. Third, as a newly independent country, Indonesia is still lack of legal scholars and lawyers to deal with judicial review. Last, judicial review somehow reflecting the idea of individualism which is not in line with the Indonesian value which value togetherness (family principle) 
Others believe that inserting judicial review in the Constitution is crucial. This is because judicial review guarantees the right of the people. It ensures that the constitutional rights of the citizens are constitutionally protected. (Muh Yamin, 1959: 330). Judicial review also limits the powers of state institutions. The founding fathers finally decided that the first constitution does not include judicial review. This decision does not mean that Indonesia reject the idea of judicial review but it is not yet the right time to apply judicial review considering the abovementioned arguments.

\section{B. Article 22 E, Article 18 (4) of the 1945 Constitution and the Power of the MK to Settle Dispute of Regional Head Election.}

The 1945 updated Constitution defines five different elections: the President and vice president election; the DPR Election; the DPD election; The DPRD election and the regional head election. the first three elections are the election on national level while the last two elections are the regional elections.

One significant change as a result of the constitutional amendment in 1999-2002 is the establishment of a new special Court namely the Constitutional Court (the MK) beside the already existing judicial body the Supreme Court (the MA). Article $24 \mathrm{C}$ of the updated Constitution stipulates the MK has five responsibilities. One of them is to settle dispute on general election result. This provision explains the MK has the authority to resolve dispute on general election result. However, it does not specify whether or not the regional head election included in the power of the MK.

Concerning regional head elections, the new Constitution provides specific Chapter on Regional Governance which consist of Articles 18, 18A, and 18B. Article 18 (4) explains Governor, Regents and Mayors respectively as head of province, Regency and city shall be elected democratically. This Chapter does not explain the dispute resolution mechanism in case there is a dispute regarding the result of regional head election.

Beside Article 18 (4), the updated Constitution also explains other types of general elections. It is mentioned in Article $22 \mathrm{E}$ Chapter VIIB on General Election. Article $22 \mathrm{E}$ consists of $6 \mathrm{sub}$ articles. Sub Article (2) stipulates that "General Election is conducted to elect members of People Representative Council (the DPR), Regional Representative Council (the DPD), President and vice President and Regional People Representative Council (the DPRD). Article 22E does not explain dispute resolution in case there is a conflict regarding the result of general election. It is clear that Article 18 (4) and Article $22 \mathrm{E}$ do not determine the mechanism to settle dispute in case there is case regarding the result of elections.

If this is the case, who has the authority to settle general election dispute then? Article $24 \mathrm{C}$ determines the power of the MK to resolve dispute on general election. It appears that this Article is associated with Article 22E on General Election. This is because Article $24 \mathrm{C}$ clearly mentions about General Election. Article 22E also explains about general elections and the types of general elections. It should be aware however the Supreme Court hold the powers of the Constitutional Court temporarily until the constitutional court officially established in 2003. 
But does Article $24 \mathrm{C}$ have strong connection with Article 18(4)? The short answer is no. Article 18 (4) is under Chapter on Regional Governance which is not specifically explain about general election. This becomes the popular opinions among constitutional law scholars including the first generation of the Constitutional Court under Prof. Jimly Asshidiqqie. The MK (2003-2008) excludes the authority to settle dispute on the regional head election as one of its main powers. This attitude is supported by Article 106 (1) of the 32/2004 Law on Regional Governance which determine that authority to settle dispute on regional head election is in the hand of Supreme Court (Stefanus Hendrianto and Fritz Siregar, 2015: 6). This concludes that there are two different authorities -the MA and the MK- to settle dispute on regional head election and other general elections disputes.

The exclusion of the MK authority to resolve dispute concerning of regional head election changed significantly in 2007. This is because the new Law on Regional Governance in 2007 especially Article 236 determine that dispute regarding the regional head elections shall be resolved by the MK. The lawmakers believe that the regional head election is part of the general election therefore the MK has the power to resolve if any dispute arise regarding the result of the elections (Fritz Edward Siregard, 2015:140). There are three possible explanations regarding the shift of regional head election to general elections. First, Law 32/2004 change the election process from indirect to direct election. The direct election reflects the character of general election as mention in Article 22E. Second, the 2005 MK Decision revoked articles regarding the powers of Local General Election Committee (the KPUD). This means that the regional head election will no longer administered by the KPUD but it will be administered by the KPU, the Committee that is also administer the general elections (Simon Butt, 2015: 171). Third, Law 22/2007 expressly stipulates that Regional Head Election is a Direct General Election. the word "direct" is similar to the nature of general election as mentioned in Article 22E. These three factors abovementioned indicates that regional head election included in general election as mention in the Constitution. Therefore, the MK has the authority to settle dispute on regional head election.

Saldi Isra, a constitutional law scholar, believe that the trust toward the work of the $\mathrm{MK}$ is the driving force for the lawmakers to determine that the regional head election is part of the general election as mention in Article 22E. (Very Junaidi, 2013: vii). in 2008 and 2013 period there are about 550 cases on regional head elections dispute. Around $50 \%$ is rejected and about $50 \%$ of the total cases are granted. I concur with Isra's view in the sense that public are confident with the Constitutional Court work. The Court performance is higly appreciated by the public.

The transfer authority from the MA to the MK is furthered by the agreement between the MA and the MK in 2008. The 22/2007 Law on Regional Governance becomes the foundation of the MK to obtain its additional powers to resolve dispute on regional head election. From the perspective of law on legislation, adding the MK power to settle dispute on regional head election through amending the Regional Governance Law raise a question. This is because the genesis of the MK authorities is expressly and limitedly regulated in the Constitution. But why adding the Court constitutional power is only 
based on the revision of law and not through constitutional amendment. hierarchically, the Law is lower than the Constitution. Since the origin of Constitutional Court authorities is stipulated in the Constitution, the addition of Court power should also be based on the Constitution not based on law.

The Court new authority to settle dispute on regional head election can be seen as the role of the MK as the guardian of the Constitution as well as the guardian of democracy. The consequence of this new authority is the more cases on dispute of regional head election submitted before the Court. Nationally there are 34 provinces and over 500 districts and cities. all together there will be around 534 regional head elections. This is not small number considering that there is only one Constitutional Court for the entire country. This coupled by the fact that there is a time limit in settling dispute of regional head elections for instance for legislative elections 30 days and 14 days for regional head elections. (kemendagri.go.id).

\section{C. the dynamics of the MK interpretation concerning its authority to settle dispute both general election and regional head election.}

The 1945 Constitution stipulates that the MK has the authority to settle dispute on general election (Nadirsyah Hosen, 2016:1). The first generation of the MK Justices headed by Prof. Jimly interpret that the MK has limited authority to settle dispute on general election only for types of general elections as mentioned in Article 22E. which mean limited to the presidential election, the provincial parliaments election, the district parliament election and the city parliament election. It does not include regional head elections. the MK during Jimly leadership restraint itself by only resolving dispute on general elections as mentioned in Article 22E.

Dispute of presidential election result that has been adjudicated by the Court, inter alia, The final recapitulation of the General Election Commission (The KPU) SK KPU No. 373/Kpts/KPU/Tahun 2009 tanggal 18 Agustus 2009. The dispute is between the Candidtate of President and vice president vs. the KPU. The object is about the KPU decision regarding the result of presidential election which may change the end result. The petition can be submitted within 3 X24 hours since the KPU decisions is issued.

With regard to regional head election, since the beginning deciding dispute on regional head election, the Court use three important words terstrutur, sistematis dan massif (structured, systematic and massive) as the indicators to determine whether there is a fraud in election. These indicators were not used by the Court in settling dispute on presidential election. The introduction of these three words can be seen in the MK decision Number 45/PHPU.D VII/ 2010 concerning Kotawaringin Barat regional head election.

a. Terstruktur or structured means the fraud is well planned and involving relevant officials and the administer of the elections hierarchically.

b. Sistematis or systematic means the fraud is well planned and utilized very good strategy.

c. Masif or massive means the fraud is committed massively in large scale. 
As predicted, the inclusion of regional head election into general election make the MK busy adjudicating dispute on elections, as there is only one Court that handle over 530 possible disputes nationally. So far, the MK handle its new authority properly. This can be seen the court decisions consistently acknowledged and respect that regional head election is part of the general election.

The consistency of the MK to settle dispute on regional head election change particularly after one of the MK Justices -Akil Mochtar- caught by the KPK because of bribery when he handled cases on regional head election dispute. Justice Akil Mochtar is the first Constitutional Justice that caught by the KPK on corruption case. (Kasus Suap Penanganan Sengketa Pilkada Akil Mochtar yang menggurita: Kompas). This is the biggest scandal in the history of the MK a Justice caught because of corruption and money laundering.

This incident creates a new discussion whether or not the authority to settle dispute on regional head election handled by the MK. Some agree that the MK still have this authority. First, MK had this authority since 2007. Second, the MK had proven that it is capable to handle such cases. The MK also gain significant confident from the public. Third, the MA is still undergone for significant improvement so that it is not wise to put more burden to MA.

The MK (in)consistency appears at least in three MK decisions: The Constitutional Court Decision Number 25/PHPU.D-VI/2008, the Constitutional Court Decision Number 97/PUU/2013, and the Constitutional Court Decision Number 1-2/PUU/2014. The following part analyses these three decisions to show the (in)consistency of the Court in determining its power to settle dispute the result of regional head election.

\section{Constitutional Court Decision Number 25/PHPU.D VI/2008: The need to transfer authority from the Supreme Court to the Constitutional Court.}

Two individuals, Bachiar Basri and Slamet Haryadi, the candidate of Regent in North Lampung Regency file a petition to the Court challenged the KPU decision that declared the other candidate as the elect regent. They brought the petition to the MK with consideration that MK has the authority to settle dispute on regional head election 18 months at the longest since the enactment of this Statute (Law 12/2008).

The Court states:

"frase "at the lates" means the transfer can be done before the deadline. however if such transfer is done before the deadline, legal action is needed in transferring the authority from the Supreme Court to the Constitutional Court expressly. The legal consequence is if there is no legal action to trasnfer the authority, the Court was of the opinion that it is automatically transfer once the deadline lapsed 18 months asmentioned in article $236 \mathrm{C}$ law $12 / 2008$. Since there is no legal action carry out so far, such authority is not yet transferred to the Constitutional Court.'

The above mention essentially means that the transfer of authority from the MA to the MK needs legal action. If the transfer conducted before the 18 months period lapse, it is necessary to have legal action in transferring the authority. But if the 18 months period already passed there is no need to have legal action. Such authority automatically 
transferred to the Constitutional Court. In this case the MK ruled the petition is in admissible because it is too premature and the substance of the petition cannot be examined, adjudicated, and decided by the Court. One Justice -Akil Mochtar provide dissenting opinion, For him,

“Article 236 C Law 12/2008 can be effective without waiting for the transfer authority from the Supreme Court to the Constitutional Court. The Constitutional Court owns this authority based on Articl 236 C Law 12/2008. The implementation ofthsi duty starts when there is a petition to the Court. The Court then examine the case. If the Constitutional Court has to wait the official transfer, the Constitutional Court actually has delay the implementation of the authority that has been granted by Article 236C Law 12/2008 on 28 April 2008;"

The 18 months period according to Justice Mochtar does not prevent the Court from examining, adjudicating and deciding cases on regional head election dispute. Justic Mochtar further states that referring to Article 16 (1) Law 44/ 2004 on Judicial Power, "the Court cannot refuse to examine, adjudicate, and decide cases because there is no law in place. The Court is obliged to examine and adjudicate such a case. Justice Mochtar's dissenting opinions create possibility that there will be two different institutions that can adjudicate regional head election dispute. This potentially make confusions among potential petitioners where to go to resolve their dispute.

Justice Mochtar opinion that the Constitutional Court has the authority to adjudicate regional head election is not totally right. This is because the whether or not the Court can adjudicate cases is about the absolute competence of the Court that has been expressly and limitedly mentioned in the constitution. Even though there is transfer of authority from the MA to the MK but the transfer itself requires 18 months period of transition. In other words, such authority is not yet belongs to the MK.

\section{The Court Decision No. 41/PHPU.D-VI/2008}

In the subsequence decision (the MK decision No. 41/PHPU.D-VI/2008), the Court decided that adjudicating regional head election dispute is the competence of the Court. This decision based on Article 236 C of Law 12/2008 and an agreement on the transfer of authority signed by the Chief Justice of the MA and the Chief Justice of the MK dated 29 October 2008.

\section{Court Decision 97 PUU-XI/2013: Invalidation of the MK authority to settle dispute concerning the result of regional head election}

Case No. 97/PUU XI/2013 was brought by Constitution and Legal Study Forum (Forum Kajian Hukum dan Konstitusi), law student association (BEM Fakultas Hukum) and Non governmental organization questioning the constitutionalit of Article $236 \mathrm{C}$ UU12/ 2008 against Article 1(3) and Article 22E of the Constitution. the petitioners argue 
that the MK power to settle dispute regional head election reflects, " an unconstitutional provision, violate the value of constitutionalism and potentially disturb the main power of theMK as the guardian of the Constitution. For petitioners the workload of the MK in resolving dispute on regional head election dominating the work of the MK as a result it delay the settlement of other cases in the $\mathrm{M}$ as refleted in the following statement:

Cases on general election disputes particularly on regional head election is more dominant compared to the judicia review cases. This resulted in the delay of the citizens who want to file judicial review cases to defend their constitutional rights because of the law violate the constitutional rights of the citizens as expressly mentioned in the constitution because the Constitutional Court is busy handling regional head election disputes;

The transfer of authority from the MA to the MK originally from the MK ruling 07273/PUU-II/2004, which state:

"As a consequence of the petitioners' opinion who state that direct regional head election fall under the definition of general election as stated in Article 22E of the 1945 Constitution which then elaborated by Law 12/2003. the dispute on election, according to the petitioners, should be decided by the Constitutional Court. Concerning the petition to declare Articles 106 (1) to (7) are inconsistent with the Constitution the Constitutional Court is of the opinion that constitutionally the lawmakers may broaden or narrow the scope of general election."

The above quotation generally stated that it is the authority of the lawmaker to determine whether the authority to settle dispute on regional head election shall be in the hand of the MA or the MK. Based on this legal consideration, the lawmaker states that regional head election is part of the general election as mentioned in Law 22/2007, Article 236C UU12/2008 and Article 29(1) latter e Law $48 / 2009$.

In the 2014 Decision, the MK in its legal consideration states that

The Constitutional Court has to be strict in interpreting the Constitution in case the Constitution has clearly regulates about things. In the event that the Court has should interpret the provision of the Constitution, the Court should apply original intent, textual, and grammatical approaches. The Court cannot deviate from what has been clearly defined by the Constitution. the Court should refrain itself in interpreting the provision of the Constitution otherwise the Court take over the drafters of the constitutions duty in writing a Constitution, through its rulings."

The above quote generally explain that the Court should limit itself in interpreting the norms of the Constitution. Using the original intent, textual, and grammatical approach the Court come to the conclusion that the authority of the Constitutional Court has been expressly and limitedly defined only to settle dispute concerning the result of general 
election, excluding the regional head election. The Court, therefore, does not have the authority to settle dispute on regional head election. The Court further states that even though the Court had different decision compared to the two previous decisions based on Law 12/2008 and Law 48/2009 do not automatically null and void. This is based on the presumtio iustitia causa in which law shall be considered valid and constitutional until it is declared by the Court the opposite. In its ruling, the Court grants the petition and states that Article 236C inconsistent with the 1945 Constitution and therefore it is not legally binding.

Two Justices -Justices Arif Hidayat and Usman Anwar- dissent. Justice Hidayat is of the opinion that it is not easy to find the original intent of the framers of the Constitution (The MK decision 97/PUU-XI/2013 hlm. 66-67). This is because the opinion of the Constitutional drafters is very dynamic. The time difference between drafting and implementing the Constitution is also significant. It is therefore important to interpret the Constitution based on the principles of the living constitution should be used instead of using the original intent.

Justice Usman is of the opinion that essentially the regional head election in many ways is similar to general election as mentioned in Article 22E. This is because: (1) they use the same principles direct, general, free, secret honest and fairness (Luberjurdil) (2) they both aim to elect leader (national or regional level). (3) both participants are endorsed by a political party or a coalition of political party (4) the body to administer these elections is the same the KPU which is independent, national and permanent in nature. Based on the above reasons, the direct election for regional head is part of general election as mentioned in Article 22E of the 1945 Constitution.

\section{The dynamics of the MK authority to settle dispute of regional head election result}

First, since its establishment in 2003 the MK excluded regional head election dispute as one of its authorities. This is because the first Chief Justice of Constitutional Court, Prof Jimly, believed that the Constitution limit the term general elections as mention in article 22E which exclude the regional head election. (Stefanus Hendrianto 2018: 5) During his leadership (2003-3008) Constitutional Court only settle dispute on general election as mention in article 22E. The Court restraint itself and consistent to settle dispute based on article 22E.

Second, since 2004 Court ruled that it is the domain of the lawmakers to determine whether or not regional head election would be conducted direct election or indirect election. Since then the lawmakers decided to adopt direct election for regional head election as reflected in Law 22/2007 and Law 32/2004 as amended by Law 12/2008. During this period, the MK was led by Chief Justice Mahfud MD. During Mahfud term of office, MK settled dispute regional head election result. 
Third, the inclusion of regional head election dispute settlement as one of the MK authorities, the MK flooded by cases regarding dispute on regional head elections. This is not surprising because Indonesia has over 550 provinces, districts and municipalities. These many cases on regional head election open possibility of corruption. This is because the parties involved in the dispute have resources. The disputing parties also expected that the MK become their last resort to win the competition. MK under Justice Jimly and Justice Mahfud are able to maintain the credibility of the MK even when the MK during Mahfud leadership handle cases regarding regional head elections. After Mahfud era however the MK was led by Akil Mochtar. During Mochtar era the MK credibility is questioned this is especially after the bribery cases which involved Justice Mochtar. (Stefanus Hendrianto 2016: 27) Justice Mochtar accept bribery from the disputing party to win a case in regional head election. Justice Mochtar caught red handedly for bribery case.

Fourth, Since Justice Akil Mochtar was caught the KPK (The Indonesian AntiCorruption Commission), the Court was very cautious in deciding cases related to regional head election (Theunis R. Roux and Fritz E. Siregar, 2016). In 2013 the Court accepted a petition which question the constitutionality of Article 236 C of Law 12/2008 against Article 1(3) and Article $22 \mathrm{E}$ of the 1945 Constitution. In this period, the Court was under the leadership of Chief Justice Hamdan Zoelva. Under Zoelva leadership, the Court was more restrained compared to the MK under Jimly and Mahfud. In this case the Court shift its legal consideration from its previous decisions. The Court acknowledges that in its previous decisions the Court had ruled that it is the domain of the lawmaker to determine whether the regional head is directly or indirectly elected. However, if we, the Court stated, look at the original intention of the framers of the Constitution, the regional head election is meant to be different from the general election as mentioned in Article 22E. Based on this constitutional interpretation, the Court ruled that regional head election is different from general election as stated in Article 22E. Regional head election is part of regional government regime as mentioned in Article 18. The Court ruled that Article 236 C of Law 12/2008 was unconstitutional. However, the invalidation of article $236 \mathrm{C}$ does not mean that the regional head election which were conducted under Article 236 become unconstitutional. To prevent legal vacuum, before a special institution established with the mandate to settle dispute regarding regional head election such authority shall be carried out by the MK.

\section{E. Why in different period there is a tendency that the Court interpret its power to settled dispute on regional head election differently?}

There are at least two factors-external and internal factors- which can explain the Court attitude toward its power to resolve dispute on regional head election. These include the provisions of the Constitution and the change of the court attitude. The external factor namely Article 24 of the 1945 Constitution influences the Court attitude as reflected in the first generation of the Constitutional Court Justices under Justice Asshidiqqie leadership (2003-08). The Court consistently followed the words of the Constitution by limiting itself 
to settle dispute regarding general election as mention in Article 22E. That said the Court has the power to settle dispute regarding general election and not the regional head election. The regional head election dispute is adjudicated by the supreme court (the MA).

In the second generation under Justice Mahfud, another external factor i.e. the change of Law 22/2007 and Law 12/2008 add the authority of the Court to adjudicate cases related to regional head election, beside the general election as stated in Article 22E. The Court determines the method of regional head election, either direct or indirect election, is the domain of the lawmakers to decide. Based on these two laws, the Court has the power to settle dispute regarding regional head election, as these two laws mention that regional head election is part of general election regime and not under the regional governance regime.

Under the third generation led by Justice Akil Mochtar, the Court was flooded by cases related to regional head election dispute. During this period, the Court experience difficult time, the Chief Justice Akil Mochtar was caught by the KPK for bribery case. The Deputy of Constitutional Court Justices, Justice Hamdan Zoelva then act as the Chief Justice of the Constitutional Court.

Under Justice Zoelva, there is a tendency that the Court is act as a refrained or restrained Court. This can be seen for example the Court reluctant to adjudicate cases related to regional head election. This can be proved when the Court decided judicial review case which question the constitutionality of Article 236 of Law12/2008. In this case, the Court was of the opinion that based on the Court interpretation of the original intention of the framers of the Constitution, Article 236 was unconstitutional. This Article is inconsistent with the intention of the framers which differentiate the general election and the regional head election.

\section{Conclusion}

1. This paper has answered two important questions. First, with regard to the first question regarding whether the Updated Constitution determine the power of the Constitutional Court to settle dispute on regional head election? It can be concluded that the power of the Court to settle dispute regarding regional head election is somewhat dynamic. Even though the Constitution differentiate between regional head election and general election, factually the Laws provide different interpretation. Since the enactment of Law 22/2007 and Law 12/2008 the Court is granted with additional power namely the settling dispute regarding regional head election. These two laws also shift the power to settle dispute on regional head election from the supreme court to the constitutional court.

2. Second, the MK somehow provides different interpretation regarding its the power to settle general election dispute. Since its inception in 2003, the MK (2003-08) limit its power by consistently follow the provision of the Constitution that differentiate general election and regional head election. However, the MK (2008-2013) through the 
amendment of the general election Laws (Laws 22/2007) and Law 23/2004 on Regional Governance gained its additional power to adjudicate regional head election dispute. But the Court through its ruling returned to its original authorities and exclude the power to settle regional head election dispute by declaring that the power

of the court to settle dispute on regional head election was unconstitutional.

\section{Recommendations}

Consistent attitude is an important character of a court. It plays important roles in maintaining the public confidence and good reputation of the Court. In interpreting the law, the Court should be consistent regardless who lead to Court. This guarantee the legal certainty, legal predictability and court credibility. For public at large, the Court consistency give public trust to the Court. Therefore, this paper suggests that the Court should be consistent in interpreting the norms of the constitution. In doing so, The Court should avoid the frequent use of extensive interpretation. And finally the Court should be loyal to the Constitution as the Court is the guardian of the Constitution.

\section{BIBLIOGRAPHY:}

\section{Books:}

Hikmahanto Juwana. (2014). Courts in Indonesia: A mix of Western and Local Character in Asian Courts in Context Eds Jiunn Rong Yeh and Wen Chen Chang Cambridge.

Jimly Asshiddiqie. (2009). Creating a Constitutional Court for a New Democracy*1-24 (Centre for Comparative Constitutional Studies Asian Law Melbourne Law School, 2009).

Muh Yamin. (1959). Naskah persiapan undang-undang dasar 1945, memuat segala naskah rasmi penggalang UUD'45 jang berlaku kembali dalam Negara Kesatuan Republik Indonesia: Jajasan Prapantja.

Petra Stockmann. (2007). The New Indonesian Constitutional Court: A study into its beginnings and first years of work. Hanns Seidel Foundation.

Saafroedin Bahar, and Nanie Hudawatie. (1995). Risalah Sidang BPUPKI Dan PPKI

Simon Butt, \& Tim Lindsey. (2012). The constitution of Indonesia: a contextual analysis. Bloomsbury Publishing.

Simon Butt. (2015). The Constitutional Court and Democracy in Indonesia. Brill.

Stefanus Hendrianto and Fritz Siregar. (2015). Development in Indonesian Constitutional Law: The Year 2015 in Review, Iconnectblog.com/2016/11/development-inindonesianconstitutional-law-the-year-2015-in-review / 
Stefanus Hendrianto. (2010). Institutional choice and the new Indonesian Constitutional Court. New Courts in Asia, edited by Andrew Harding and Penelope (Pip) Nicholson. London: Routledge, 2010, 158-77.

Stefanus Hendrianto. (2018). Law and politics of constitutional courts: Indonesia and the search for judicial heroes. Routledge.

Tamir Moustafa. (2008). Tom Ginsburg ed, Rule by Law: The Politics of Courts in Authoritarian Regimes.

Tim Lindsey. (2008). Constitutional Reform in Indonesia: Muddling toward democracy in Law and Society. $2^{\text {nd }}$ Edition Edited by Tim Lindsey. Federation Press.

Tim Penyusun. (2008). Menegakkan Tiang Konstitusi: Memoar Lima Tahun Kepemimpinan Prof. Dr. Jimly Asshiddiqie, S.H. Di Mahkamah Konstitusi at 5 "Upholding the Pilar of the Constitution: Memoar five years of the Leadership of Prof. Dr. Jimly Asshiddiqie". Jakarta: Sekretariat jenderal dan Kepaniteraan Mahkamah Konstitusi $1^{\text {st }}$ ed.

Tom Ginsburg. (2003). Judicial review in new democracies: Constitutional courts in Asian cases. Cambridge University Press.

Valina Singka Subekti, V. S. (2007). Menyusun konstitusi transisi: pergulatan kepentingan dan pemikiran dalam proses perubahan UUD 1945 "Formulating a transitional Constitution: the struggle of interests and thoughts in the 1945 constitutional amendments". RajaGrafindo Persada.

\section{Journals:}

Fritz E. Siregar. (2015), The Political Context of Judicial Review in Indonesia. Indon. L. Rev., 5, 208.

Nadirsyah Hosen. (2016). The Constitutional Court and 'Islamic'Judges in Indonesia. Australian Journal of Asian Law, 16(2).

Stefanus Hendrianto. (2016). Convergence or Borrowing: Standing in the Indonesian Constitutional Court. Constitutional Review, 1(1), $28-49$.

Stefanus Hendrianto. (2016). The Rise and Fall of Heroic Chief Justices: Constitutional Politics and Judicial Leadership in Indonesia. Pac. Rim L. \& Pol'y J., 25, 489.

Theunis R. Roux and Fritz E. Siregar. (2016). Trajectories of Curial Power: The Rise, Fall and Partial Rehabilitation of the Indonesian Constitutional Court, Australian Journal of Asian Law Vol 16 No. 2, 2016 


\section{Legal Documents:}

The 1945 Constitution of The Republic of Indonesia

Law Number 24 of 2003 on The Constitutional Court (State Gazette Number 98 of 2003, Additional State Gazette 4316)

Law Number 32 of 2004 on Regional Governance (State Gazette Number 125 of 2004, Additional State Gazette 4437)

Law Number 22 of 2007 on The Administers of General (State Gazette Number 59 of 2007, Additional State Gazette 4721)

Law Number 12 of 2008 on the amendment of Law Number 32 of 2004 on Regional Governance (State Gazette Number 59 of 2008, Additional State Gazette 4844)

The Constitutional Court Decision Number 45/PHPU.D VII/2010

The Constitutional Court Decision Number 25/PHPU.D-VI/2008,

The Constitutional Court Decision Number 97/PUU/2013

The Constitutional Court Decision Number 1-2/PUU/2014.

The Constitutional Court Decision Number 41/PHPU.D-VI/ 2008 